\title{
CHOIRS AND CHOIR SCHOOLS SINCE THE REFORMATION
}

\author{
II.-THE REVIVAL
}

THE lot of the choristers during the eighteenth century was far from being an enviable one. The capitular bodies were not over particular about the rendering of the services; and the boys, being of little or no consequence in their eyes, were left very much to the tender mercies of the organist and choirmaster. The music copies were allowed to become corrupt, and careless copying was responsible for numerous mistakes. The century produced its great musicians, but they could make little headway against the prevailing apathy and neglect. Dr. Alcock, who had been a chorister at St. Paul's under Charles King, after visiting many cathedrals, complained that he had never come across music books " without numberless mistakes." The need for accurate copies was urgent, yet when William Boyce, after twelve years' labour, brought out his edition of Cathedral Music, he did little more than recover his out-of-pocket expenses. The principal subscribers were not the cathedral bodies, but private individuals. Only nine copies were purchased for use in St. Paul's Cathedral. The outlook for music lovers was certainly far from promising.

Far too little attention was paid to the education of choristers. In this respect the Church but reflected the spirit of the age, far too little interest being taken in any proposals for the improvement of national education. With this environment we cannot expect much from Choir Schools, which were generally in the hands of Deans and Chapters not renowned for their generosity. In the pre-Reformation period the services were in Latin, and all choristers had to receive some classical training. This necessity disappeared when the service books were translated, and although the schools continued the existing curriculum for a time, this was mainly due to the force of inherited custom. In the eighteenth century this tradition belonged to the remote past, and in many cathedrals the education was very little above the standard of the average National School, which in those days was of a very elementary character. The boys were selected because of their vocal powers, and the cathedrals and services, together with sundry and various concert parties, took up the greater part of their time. No schoolmaster wanted boys who were likely to upset his time-table, coming in at all hours, and leaving whenever it suited the Almoner's convenience to withdraw them. The 
choristers at Westminster Abbey found a champion in Benjamin Cooke, the organist there during the latter part of the century. Cooke found that, according to the statutes of the college, the choristers possessed certain rights at the election of scholars, and pressed their claims until he secured for them the right of admission to the school. His successors were not equally keen, and the right fell into abeyance, possibly because, as Mr. John Sargeaunt suggests in his Annals of Westminster School, the boys were drawn from a class "for which a classical education was unsuitable." No doubt it was a difficult matter to arrange for the boys to attend at the usual school hours, and consequently Cooke's successors, wanting to have the boys entirely under their own control, were not very particular whether they went to school or not. Very likely the boys were not particularly anxious to avail themselves of their privileges, preferring outdoor life with its freedom to the routine and discipline of the classroom. It is said that the Westminster choristers spent their time between the services in St. Margaret's Churchyard, sailing toy boats in the puddles caused by the sinking of gravestones, or playing marbles on the flat slabs of altar tombs. This was the state of affairs right up to the fourth decade of the nineteenth century, when Dean Buckland opened a schoolroom, and appointed an Oxford friend as master. This was the origin of the present Westminster Choir School. It may surprise some people to learn that the Abbey choristers were at one time not unlike the naughty little boys at a suburban parish church.

At Durham, in 1819, the singing boys received a charity education, and wore a corresponding dress. They were, however, given precedence over the Grammar School boys when, in accordance with an ancient privilege, they attended the members of the Chapter after dinner, and read portions of Scripture to them. When this was over, a Canon Residentiary proceeded to address the boys in Latin!

Somewhat better treatment was meted out to the choristers at Exeter, where arrangements were made for the boys to have the benefit of a classical education, with the addition of writing and arithmetic. Parents were required to notify the Dean and Chapter if they wished their boys to attend these classes; but the advantages of a higher education were within the reach of all who cared to avail themselves of them. Throughout the eighteenth century there was at Exeter a choral celebration once a month, and on all Great Festivals. When the Bishop was present, the choristers preceded him as he left the church, kneeling to receive his blessing before he passed into his vestry. It was still the custom for them to do this in the days of Bishop 
Phillpotts, the well-known Bishop of that diocese. Strange to say, this city, where at any rate the outward witness to Catholic practice was retained, was also the scene of disgraceful riots when certain clergy discarded the black gown in favour of the surplice.

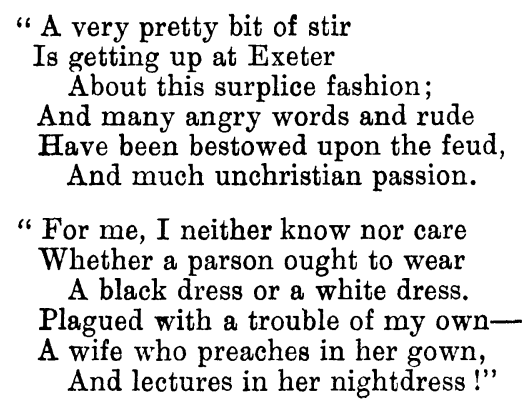

Ely was another cathedral where Catholic ceremonial was retained, incense being burnt at the High Altar on all Great Festivals right up to the end of the eighteenth century. The Chapter do not appear to have interested themselves very much in the choir. There were eight choristers, but they received no education except in music. In 1831 the organist was a certain Mr. Janes. In order to improve the service, he proposed to harmonize the Versicles and Responses, and started with the General Confession. He, however, got no farther, for the Minor Canons, who were unable to chant, combined and threatened him with dire penalties for presuming to lengthen the service!

At Wells the nave of the cathedral was used as a playground by the singing boys, who, among other forms of amusement, found pleasure in the pastime of throwing stones. James Turle was a chorister at Wells during the early years of the nineteenth century, and on one occasion he broke some glass in one of the windows, throwing a stone through St. Andrew's nose. Years after a verger, pointing to the damage, added, "That was done by the present organist of Westminster Abbey."

With the dawn of the nineteenth century came the temporary closing of the Choristers' School at St. Paul's. From being one of the premier schools in the kingdom, it had gradually declined. During the eighteenth century there were only eight boys who lived with the Almoner at his residence. Meantime the cost of living had risen considerably (present-day folk know well what that means), and when John Sale was appointed Almoner, he found the allowance for the maintenance of the boys insufficient to pay expenses. At that time he was receiving about $£ 80$ a year. The Dean and Chapter had let the cathedral estates at quite nominal rents, and there were no 
available funds to spend on the boys. There was no alternative except to close the school, and divide what money there was among the boys. Thus St. Paul's came to have a non-resident choir. The Almoner managed to earn a precarious livelihood by hiring the boys out for public and private concerts, with the result that choristers were out all hours of the night, and their condition became a scandal to the Church. No school would receive them, and, except as regards singing, their education was entirely neglected. Rarely, if ever, were they called upon to repeat the Catechism.

The use of choristers for concert parties was, as has been already mentioned, fairly general. At Norwich, in the days of Zechariah Buck, who was organist there, 1819-1877, a clergyman in the diocese asked him to lend a boy to assist in the solos at a rendering of Mendelssohn's Elijah. The boy sent was A. R. Gaul, afterwards organist at Birmingham. The music was preceded by a dinner, and soon after the invited guests had taken their places a note was brought in and handed to the host; it was from Zechariah Buck, and read as follows: "Dear Sir,-Please don't let little Gaul have any pudding.-Yours faithfully, Z. Buck." One may be forgiven for indulging the hope that "little Gaul" had his pudding after all.

About this time Maria Hackett began to take an interest in the boys. She was born in 1783, and lived to a good old age, dying at 3, Manor Villas, Amhurst Road, in 1874. She was a regular attendant at St. Paul's Cathedral, and spent the whole of her long life in seeking to bring about some improvement in the condition of cathedral choristers. In 1810 she placed a fatherless boy in the choir at St. Paul's, and finding that he was not receiving a classical education, she made enquiries to ascertain the reason for this omission. Upon discovering that the original endowments had been diverted to other uses, she wrote numerous letters. The Bishop, Dean, and Canons all alike received communications from her, pointing out the urgency of reform, and reminding them of their duty. The Dean flatly refused to allow Miss Hackett to inspect the trust deeds in the muniment room at St. Paul's, rightly fearing that information gained from that source would be used as evidence against himself. The necessary evidence was, however, obtained from documents in the British Museum, and, armed with this, Miss Hackett met the persistent refusals of the Dean and Chapter with a threat of legal proceedings. A compromise was now effected, the Chancellor promising to appropriate a fair proportion of the revenues of his stall in order to make some provision for the classical education of the choristers. The Almoner's salary was increased to about $£ 217$, and William 
Hawes appointed. In $1830 \mathrm{it}$ was raised again, this time to $£ 350$, with the addition of some fines payable on the renewal of certain leases. This meant an allowance of about $£ 50$ a year for each boy. Upon his appointment in 1817 as Master of the Chapel Royal, Hawes removed to 7, Adelphi Terrace, Strand, which for nearly thirty years was the home of both sets of choristers.

Hawes, like many of his contemporaries, was renowned for his floggings. An old pupil, on being asked whether he remembered his boyhood days with Hawes, returned the significant answer: "Can I ever forget them?" Many of his pupils in after years distinguished themselves in the musical world, and among these were John Hopkins, the organist at Rochester Cathedral (1856-1900), Edward J. Hopkins, and Samuel Sebastian Wesley. The last named was described by Hawes as one of the best boys he ever had, and he was one of the two choristers selected to sing at the private chapel at Brighton whenever George IV. was in residence there. The King presented the boy with a gold watch on discovering that he was a nephew of his own private organist, Charles Wesley, in whose musical career both he and his father had taken a great interest. There is a story told about another of Hawes's pupils which has become well known by being (rightly or wrongly) associated with other schoolmasters. The boy was William Makepeace, who for fifty years was Master of the Choristers at Rochester. On one occasion the boy asked Hawes for a holiday, telling him that it was his birthday. Hawes, remembering that considerably less than a year had elapsed since the boy had come to him with a similar request, looked at him sternly and said: "If you have another birthday before a twelvemonth has passed, I'll thrash you within an inch of your life."

Hawes was a stern disciplinarian in school hours, but the boys did very much as they pleased in their spare time. The elder lads were often guilty of cruelty; practical jokes and merciless bullying were far too common. Cases were known of brutal ill-treatment, and sometimes small boys were put on the roof on a frosty night with no covering but their nightdress, and left there for hours. Perhaps it would have been as well had Hawes been a little more lenient in school hours, and a little stricter during the time supposed to be spent in rest and recreation.

Hawes's boys were in great demand at concerts and public dinners. Every Sunday and Thursday there were private concerts at the master's house, and it has been said that within three months of his appointment in 1812 the boys had fifty public engagements in addition to their regular duties. Capable boys were not allowed much rest. The two senior chapel boys III. 16 
used to sing at the cathedral on Sunday as well as at the Chapel Royal. The services at St. Paul's were at 9.45 and 3.0 ; and at the Chapel Royal at 12 and 5.30. Royal choristers wore a scarlet and gold costume, and the two boys in the course of their four journeys between the cathedral and the Chapel Royal had to call at the house in Adelphi Terrace to don or put off this distinctive dress. They did not have much time to themselves until the last Evensong was finished.

The lot of the choristers had been improved, but Miss Hackett was far from satisfied. The behaviour in church left very much to be desired. The following extracts appear in the diary she kept in 1834:

"The choristers ran into church heated and breathless after the service had commenced."

"Sat., Sept. 6.-In the Creed and Lord's Prayer all parties seemed to be running races to try who should first reach the Amen."

"Sun., Sept. 7.-A numerous choir at the commencement of the service, but gradually diminished, till, at sermon, only the succentor and six boys."

"Sun., Sept. 21.-The whole choir withdrew before sermon, excepting one Minor Canon, one Vicar Choral, and five boys."

The Precentor at that time was the Rev. C. Almeric Belli. He was appointed in 1819, and died in 1886 at the advanced age of ninety-four. No doubt he did excellent work elsewhere, but he was seldom seen at St. Paul's. The witty Sydney Smith used to speak of him as the "Absenter." It is said that in 1852 he came to St. Paul's for some public function (supposed to be the funeral of the Duke of Wellington), but the officials, not recognizing him, refused to allow him to enter the cathedral. Still he was Precentor, even if his visits were few and far between, and at his death some mention had to be made of the gentleman in the cathedral report. His obituary notice read as follows: "Mr. Belli, in so accepting and holding office, was only acquiescing in an order of things which he found, and which probably had existed long before his time."

After Hawes's death in 1846 Bishop Blomfield appointed the Rev. Thomas Helmore, of plainsong fame, as the master of the Chapel Royal boys. He took them to his house in Robert Street, and St. Paul's boys were once again without a residence. They lived at their homes, and came to school every day. Hawes's successor was the Ven. W. Hale Hale, who held several appointments. He was Canon of St. Paul's, Archdeacon of London, Rector of Cripplegate, and Master of the Charterhouse. His total income was about $£ 4,000$ a year, with various other emoluments. To these duties were now added those of the 
Almoner of St. Paul's, which, however, he only retained for two years. On one occasion an inmate of the Charterhouse appeared in chapel without having performed the necessary preliminary ablutions, and whose person betrayed the need of a liberal application of soap and water. Hale, taking the culprit to task, asked him: "Have you forgotten that vermin were sent as a plague upon the Egyptians?" "Ah, sir," replied the old man, "a worse plague than vermin was sent. Hail was sent."

In 1848 the Rev. J. H. Coward was appointed Almoner of St. Paul's. The boys continued to live at home, but the school curriculum was greatly improved, and included religious knowledge, Latin, reading, English composition, and arithmetic. A music master was added to the staff to give lessons in vocal and instrumental music. Under a benefaction dating from 1837 the gratuity to the boys on leaving was increased from $£ 10$ to $£ 30$. In 1853 a rule was framed forbidding the boys to sing anywhere except at the cathedral without the knowledge and permission of the Almoner. (This was the revival of an old statute which had been disregarded for centuries.) Thus, the pernicious custom of hiring out boys for concert parties came to an end. There was still a considerable amount of uphill work. The Dean and Chapter took little interest in the choir. In 1860 they accepted $£ 100$ bequeathed as a trust to provide an annual prize for the best Latin scholar. They took the money, but neither appointed examiners nor awarded the prize; and a satisfactory settlement was only arrived at after considerable trouble. Once again the indefatigable Miss Hackett was to the fore. Whenever the rights of choristers were in danger, her energy knew no bounds until they obtained just and fair treatment.

In 1871 the deanery of St. Paul's was offered to R. W. Church. At last the choir had a Dean who meant to take an interest in their welfare, and in whose eyes the reverent and devout rendering of the service was a matter of supreme moment. The Dean's estimate of his task can be found in his Life and Letters. It was far from being an easy one, for he had "to fight and reduce to order a refractory and difficult staff of singing men, strong in their charters and inherited abuses." With the boys he had to complete the good work which had been going on for over sixty years, and which owed, not only its inspiration, but its progress as well, to Miss Maria Hackett. In 1873 the choral foundation was reconstructed, and plans were drawn up for a Choristers' College to accommodate forty boys. This is the present building erected in Carter Lane at a cost of $£ 20,000$, the necessary money being obtained from the Ecclesiastical Commissioners. Dean Church laid the 
foundation stone in January, 1874, and in 1875 the new building was ready. Thirty-four boys were admitted at once, and six more were added soon after, bringing the number up to forty. There the boys receive an excellent preparatory education, with the prospect of obtaining scholarships in Public Schools when they leave the choir.

Had Miss Hackett lived a few months longer, she would have seen the complete fulfilment of her cherished schemes. When she passed away in 1874, the choir at St. Paul's, at their own request and expense, attended her funeral at Highgate. It was the choristers' tribute of gratitude to one who had spent a long life in their service.

Miss Hackett did not confine her attention to St. Paul's. Every cathedral was visited and reported on. In the autumn of each year she took a six weeks' tour of cathedral cities " to look after her dear children." She never went empty-handed, always carrying some little presents for the boys in whom she took so great an interest. These periodical visits were continued throughout her whole life. When she was ninety years of age she visited St. David's, and three months before her death she was at Canterbury. In the early years of her life she wrote: "If life and leisure are afforded me, I trust these powerless members of the choir, so long as they require a friend, will find in me an ardent and disinterested advocate to the utmost of my abilities." Life and leisure were afforded her, and the wish expressed in that letter had abundant fulfilment throughout the course of the great revival of our English Choir Schools. Her name will be handed down to posterity as the "Choristers' Friend."

No survey of Choir Schools, however brief, would be complete without some reference to the work of another famous Churchman, who gave not only his time, but also his wealth, to beautify the services of the English Church. In 1843 Sir Frederick Ouseley went to Oxford, and just before completing his course temporarily filled the post of organist at Christ Church. In 1849 he was ordained deacon at St. Paul's, and licensed to the curacy of St. Paul's, Knightsbridge. While he was there St. Barnabas, Pimlico, was opened as a chapel-of-ease. The church was dedicated on the Feast of St. Barnabas, and from the start arrangements were made for daily choral services. Near the church were collegiate buildings, where the choristers were boarded and educated. The disgraceful riots which took place at this church are now a piece of familiar history, and need no more than passing mention. After the Rev. W. J. Bennett's resignation in March, 1851, Sir Frederick Ouseley gathered the boys together at Lovehill House, Langley Marsh, near Windsor. 
There in a small private chapel the choral services were continued until some better provision could be made. Meantime Sir Frederick Ouseley purchased an estate at Tenbury, and in 1854 the foundation stone of St. Michael's Collegiate Church was laid. The church was completed and consecrated September 29, 1856, with collegiate buildings attached, and with every convenience for the maintenance and education of the choristers. Meantime, in 1855, Sir Frederick Ouseley was ordained priest and appointed Precentor of Hereford Cathedral, which post he held jointly with the benefice of St. Michael's. The buildings of his own foundation cost him somewhere about

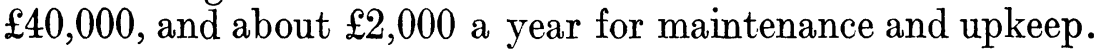
His aim was to provide a model for the choral services throughout the country, and with this object in view he gave his wealth ungrudgingly for the good of the Church. The college provided a high-class preparatory education for the sons of gentlemen, and from Tenbury the boys were passed on to one or other of the great Public Schools. It was "the first school of the kind established since the Reformation." Its permanence was secured by an additional endowment of $£ 20,000$, a legacy from the Hon. Miss Georgina Rushout, a friend of the founder, and one who had always taken a deep personal interest in his schemes. If Miss Hackett was instrumental in arousing public opinion in favour of the choristers, it was Sir Frederick Ouseley who, by providing a model school, showed the kind of school which every cathedral ought to possess.

In 1880 a representative meeting of organists met in the Chapter House of St. Paul's, and passed a resolution recommending that no cathedral choir should contain less than twenty men and twelve boys, and that the boys should, in addition to board and lodging, receive a sound classical education. Public opinion had been aroused, thanks largely to the unwearying efforts of disinterested and enthusiastic pioneers, and when the century closed, a wonderful change had taken place in cathedral choirs. The Cathedral Commissioners appointed in 1879 sent a list of questions to all capitular bodies. Special enquiry was made as to the condition of the Choristers' School, and of any other school connected with the body; also how the income was divided between the Dean, Canons, Minor Canons, Vicars Choral, Choristers' School, and Cathedral School. Taken as a whole, the replies were satisfactory; still, in making their report in 1883, the Commissioners recommended additional grants to certain schools to improve further the education of the choristers, and in some cases there were demands for improvements on a new and larger scale.

At the present day, a visitor to one of our great cathedrals 
would be shocked were he to find the service rendered in a careless and slovenly manner, so accustomed have we become to a beautiful and dignified choral service. It was not always so, and sometimes we are inclined to forget how great a transformation has taken place within the lifetime of the older members of the present generation.

In the symbolism of olden days, the worship of the choir was regarded as a type or picture of the worship of heaven itself, while the people in the nave represented the Church on earth. So priests taught their people in the Middle Ages. The devotion and love of Christian souls has in all ages found expression in the endeavour to make our choirs more worthy of that which in days gone by they were taken to represent. Christian people to-day owe a debt of gratitude to the composers, past and present, who have sought to make sacred music a fitting medium for the expression of the faith, hope, and love of the Church on earth.

W. Escott Bloss.

\section{PROVINCES IN THE CHURCH}

THE Anglican communion is happily making progress towards a solid and uniform organization of its several parts; perhaps it will some day develop a central synod with more than advisory functions. The "List of Bishops attending the Lambeth Conference of 1920, arranged according to Provinces," falls under no fewer than nineteen heads, all of which represent coherent geographical regions, save the one in which are grouped the scattered sees in all parts of the world which own an individual allegiance to Canterbury. And we are told that there is the immediate prospect of the branches of our communion in China and Japan "obtaining full advantage of any rights attaching to provincial organizations." In those countries are dioceses which owe their origin to the United States and to Canada, as well as others which spring from English missions and are directly dependent on Canterbury. Furthermore, there is a "possibility" of the formation of new Provinces in Eastern and Western Africa. There is a steady encroachment upon the unorganized fringe, and an increasing hope that the whole communion will in due time attain to a complete canonical structure, though some outlying portions will find it difficult to place themselves. In what Province, for instance, can the two Bishops who supervise the scattered Anglican congregations of South America find a home? And perhaps the obstacles which hinder Newfoundland from entering the political life of Canada may be effectual to keep their Churchmen apart. 